\title{
Comparison of three methods for concentration of rotavirus from artificially spiked shellfish samples
}

\author{
Vysakh Mohan ${ }^{1}$, Shriya Rawat ${ }^{2}$, K. M. Lokesh ${ }^{3}$, H. V. Mohan ${ }^{4}$, D. Avinash Reddy ${ }^{1}$, Ashok Kumar ${ }^{1}$ and K N. Bhilegaonkar $^{1}$ \\ 1. Division of Veterinary Public Health, Indian Veterinary Research Institute, Izatngar - 243122, Uttar Pradesh, \\ India; 2. Division of Veterinary Public Health, College of Veterinary and Animal Sciences, Sardar Vallabhbhai Patel \\ University of Agriculture and Technology, Modipuram, Meerut, India; 3. Division of Veterinary Public Health, \\ Guru Angad Dev Veterinary and Animal Sciences University, Ludhiana, Punjab, India; 4. Division of Veterinary Public \\ Health, Veterinary college, Bidar, Karnataka, India \\ Corresponding author: Vysakh Mohan, email: vysakhmohanvet@gmail.com \\ SR: shriyarawat@gmail.com, KML: lokeshvph@gmail.com, HVM: mohanhv@gmail.com, DAR: avi.incredible@gmail.com, \\ AK: ashokakt@rediffmail.com, KNB: kiranvph@rediffmail.com
}

Received: 01-03-2014, Revised: 03-06-2014, Accepted: 07-06-2014, Published online: 06-07-2014

doi: 10.14202/vetworld.2014.463-466 How to cite this article: Mohan V, Rawat S, Lokesh KM, Mohan HV, Avinash Reddy D, Kumar A and Bhilegaonkar KN (2014) Comparison of three methods for concentration of rotavirus from artificially spiked shellfish samples, Veterinary World 7(7): 463-466.

\begin{abstract}
Background: Shellfish are a nutritious food source whose consumption and commercial value have risen dramatically worldwide. Shellfish being filter feeders concentrate particulate matters including microorganisms such as pathogenic bacteria and viruses and thus constitute a major public health concern. Effective preliminary sample treatment steps such as concentration of virus from shellfish are essential before RNA/DNA isolation for final PCR accuracy and reproducibility due to presence of PCR inhibitors in shellfish.
\end{abstract}

Aim: The current study was done to compare three methods for concentration of rotavirus from shellfish samples.

Materials and Methods: Shellfish samples artificially spiked with tenfold serial dilutions of known concentration of rotavirus were subjected to three different concentration methods namely; proteinase $\mathrm{K}$ treatment, precipitation with polyethylene glycol 8000 and use of lysis buffer. RNA was isolated from the concentrated samples using phenol chloroform method. Rota viral RNA was detected using RT-PCR.

Results: Concentration of virus using proteinase K and lysis buffer yielded better result than concentration by PEG 8000 in samples with lowest concentration of virus. Among these two methods proteinase $\mathrm{K}$ treatment was superior as it showed better amplification of the highest dilution $\left(10^{7}\right)$ used.

Conclusion: Treatment with proteinase $\mathrm{K}$ was better than other two methods as it could detect the viral RNA in all three tenfold serial dilutions.

Keywords: concentration, lysis buffer, polyethylene glycol 8000, proteinase K, RT-PCR, shellfish.

\section{Introduction}

Shellfish is cheap and highly proteinaceous food whose consumption has increased globally. Shellfish by virtue of their filter feeding habit can concentrate pathogenic organisms such as enteric viruses and bacteria present in contaminated water [1]. A number of human enteric viruses including norovirus, aichi, rotavirus, enterovirus, adenovirus, astrovirus, sapovirus, Hepatitis A and Hepatitis E virus have been detected in shellfish, although not all have been clearly linked with documented disease outbreaks [2, 3]. Faecal indicator bacteria routinely used to access sanitary quality of water is successful only in prevention of shellfish borne infection of bacterial origin and have limited predictive value for pathogenic viruses [4]. Hence there is need for methods that can be used for direct virological examination of samples in order to access the health risk due to enteric viruses.

Copyright: The authors. This article is an open access article licensed under the terms of the Creative Commons Attribution License (http://creativecommons.org/licenses/by/2.0) which permits unrestricted use, distribution and reproduction in any medium, provided the work is properly cited.
Identification of enteric virus from shellfish is difficult due to the low concentration of virus and the presence of substances liable to interfere with enzyme system used for amplification [5,6]. The main inhibitors in shellfish are acid polysaccharides [7]. Effective preliminary sample treatment steps such as concentration of virus from shellfish are therefore essential before RNA/DNA isolation for final PCR accuracy and reproducibility [8].

The aim of the study is to compare three methods namely Proteinase K treatment $[9,10]$, precipitation with polyethylene glycol 8000 [11], and use of lysis buffer [12] for concentration of rotavirus from shellfish after artificially spiking the shellfish with known concentration of faecal sample containing rotavirus.

\section{Materials and Methods}

Processing of samples: The shellfish were washed in running tap water. The shells were shucked. The digestive diverticulum were cut into small pieces, homogenized with hand pestle and transferred to a 15 $\mathrm{ml}$ centrifuge tube for concentration and extraction of 
virus RNA. Three methods were used for the concentration of viral RNA from the shellfishes and are discussed below:

Proteinase $\mathrm{K}$ method: A volume of $1 \mathrm{ml}$ of proteinase $\mathrm{K}$ $(100 \mu \mathrm{g} / \mathrm{ml})$ (Fermentas) was added to the centrifuge tubes containing $1 \mathrm{~g}$ homogenized shellfish tissue. It was then kept in shaking incubator at $180 \mathrm{rpm}$ at a temperature of $37^{\circ} \mathrm{C}$ for $1 \mathrm{~h}$. Proteinase $\mathrm{K}$ was inactivated by incubating in water bath at $65^{\circ} \mathrm{C}$ for 15 min. The supernatant was collected after centrifugation at $3000 \mathrm{rpm}$ for $5 \mathrm{~min}$ and stored at $-20^{\circ} \mathrm{C}$.

Lysis buffer method: Nearly $1 \mathrm{~g}$ homogenized shellfish tissue was taken in a $15 \mathrm{ml}$ centrifuge tube and equal volume of lysis buffer (3M Sodium Acetate (Sarabhai M Chemicals Ltd, India) and 10\% SDS (Sisco research Laboratories Ltd), pH 5.4) was added. It was then kept in shaking incubator at $180 \mathrm{rpm}$ for $1 \mathrm{~h}$. The supernatant collected after centrifugation at $3000 \mathrm{rpm}$ was stored at $-20^{\circ} \mathrm{C}$.

Polyethylene glycol method: A volume of $5 \mathrm{ml}$ of Glycine buffer (1 M Glycine (sd-Fine Chem. Ltd, India) and $1 \mathrm{M}$ Sodium chloride (Sisco research Laboratories Ltd, India), $\mathrm{pH}$ 9) was added to $1 \mathrm{~g}$ of the homogenized shellfish tissue and centrifuged at 5000 rpm for $10 \mathrm{~min}$ at $4^{\circ} \mathrm{C}$. The supernatant was collected and $\mathrm{pH}$ adjusted to 7.2 , mixed with $20 \%$ polyethylene glycol 8000 (PEG8000) (Sisco research Laboratories Ltd) and incubated overnight at $4^{\circ} \mathrm{C}$. The incubated supernatant was centrifuged at $6200 \mathrm{rpm}$ for $20 \mathrm{~min}$ at $4^{\circ} \mathrm{C}$ and the pellet obtained was resuspended in $0.15 \mathrm{M}$ $\mathrm{Na}_{2} \mathrm{HPO}_{4}$ (Sisco research Laboratories). The final $\mathrm{pH}$ was adjusted to 7.2 and the suspension stored at $-20^{\circ} \mathrm{C}$.

Spiking of shellfish with rotavirus positive faecal sample: To evaluate the effectiveness of the various concentration methods spiking study was done using rotavirus positive faecal sample having a copy number of $9.3 \times 10^{3} / 100 \mathrm{ng}$ as control. Approximately $100 \mathrm{mg}$ of faecal sample was taken in an Eppendorf tube and the volume was made to $1 \mathrm{ml}$ with PBS. Tenfold serial of the faecal sample were made with each dilutions consisting of copy numbers of $9.3 \times 10^{9} / \mathrm{ml}, 9.3 \times$ $10^{8} / \mathrm{ml}$ and $9.3 \times 10^{7} / \mathrm{ml}$. A total of 9 homogenized shellfish samples were taken and separated to three sets, each set having three shellfish samples. The three sets of dilutions were added to three sets of shellfish such that each set of shellfish samples receive three different dilutions of faecal samples. The samples were kept undisturbed for about $5 \mathrm{~h}$. The three set of shellfish samples were subjected to the three different concentration methods described above.

Isolation of RNA by phenol: chloroform: isoamyl alcohol method: An aliquot of $1 \mathrm{ml}$ of supernatant was treated with 0.1 volumes of $10 \%$ of sodium dodecyl sulphate (SDS) and incubated for $1 \mathrm{~h}$ at $56^{\circ} \mathrm{C}$ in water bath. To this equal volume of phenol-choloroformisoamyl alcohol mixture in a ratio of 25:24:1 was added. It was vortexed and centrifuged at 12,000 $\mathrm{g}$ for
15 min. at $4^{\circ} \mathrm{C}$. The upper aqueous layer was carefully transferred to another tube without disturbing the interphase. It was mixed with equal volume of chloroform-isoamyl alcohol (24:1) and vortexed, and then the mixture was centrifuged again at $12,000 \mathrm{~g}$ for 10 min and upper clear aqueous phase transferred to fresh micro centrifuge tube. To the aqueous phase 0.1 volume of $3 \mathrm{M}$ sodium acetate and equal volume of isopropanol were added and mixed gently. The samples were kept at $-20^{\circ} \mathrm{C}$ overnight for RNA precipitation. The RNA was pelleted by centrifugation at $10,000 \mathrm{~g}$ for $15 \mathrm{~min}$. The pellet obtained was washed with $1 \mathrm{ml}$ of $70 \%$ chilled ethanol to remove excess salts by centrifuging it at 10,000 $\mathrm{g}$ for $5 \mathrm{~min}$. The pellet was air dried and suspended in $20 \mu \mathrm{l}$ nuclease free water or RNA storing solution (Amresco), heated at $56^{\circ} \mathrm{C}$ for 5$10 \mathrm{~min}$. to dissolve the pellet and stored at $-20^{\circ} \mathrm{C}$.

\section{RT-PCR for detection of rotavirus}

Preparation of cDNA: PCR tubes $(0.2 \mathrm{ml})$ were taken on ice and reaction mix was prepared as follows- $1 \mu \mathrm{l}$ each of forward and reverse primer (rota 1 and rota 2 ), $1.5 \mu 1 \mathrm{DMSO}, 5.5 \mu \mathrm{lNFW}$ and $5 \mu 1$ of dsRNA for single reaction. The tubes were spun and boiled at $95^{\circ} \mathrm{C}$ for 5 min in a thermocycler (Eppendorf, Germany) and then snap chilled on ice. Following master mixture was separately prepared and dispensed in tubes containing RNA and primers. Master mixture was prepared by adding $2.5 \mu \mathrm{l}$ of $5 \mathrm{x}$ RT buffer, $2.0 \mu \mathrm{l}$ of $0.1 \mathrm{M}$ Dithiothreitol, $0.4 \mathrm{mM}$ dNTP, $0.5 \mu \mathrm{l}$ RNAase Inhibitor (40 U/ $\mu \mathrm{l}), 1 \mu \mathrm{l}$ of M-MuLV RT $(20 \mathrm{U} / \mu \mathrm{l})$ and $4 \mu \mathrm{l}$ NFW(Fermentas). After brief centrifugation the tubes were loaded in thermo cycler under the following conditions of $37^{\circ} \mathrm{C}$ for $60 \mathrm{~min}$ and $65^{\circ} \mathrm{C}$ for $10 \mathrm{~min}$.

PCR assay: PCR mixture containing the following components was prepared- $2.5 \mu \mathrm{l}$ of 10x PCR buffer without $\mathrm{MgCl}_{2}$ (Fermentas), $1.5 \mathrm{mM} \mathrm{MgCl}_{2}$ (Fermentas), $0.2 \mathrm{mM}$ Dntp (Fermentas), $1 \mu \mathrm{l}$ each of forward and reverse primers $(10 \mathrm{pmol} / \mu \mathrm{l})(\mathrm{GCC}), 0.2$ $\mu \mathrm{Taq}$ DNA Polymerase (5 U/ $\mu \mathrm{l}$ ) (Fermentas) and 13.3 $\mu \mathrm{l} \mathrm{NFW} \mathrm{(Fermentas).} \mathrm{To} \mathrm{the} \mathrm{PCR} \mathrm{mixture} 5 \mu \mathrm{l}$ of cDNA was added. The tubes were briefly centrifuged and loaded on to thermalcycler and the cycling conditions were set as follows. After an initial denaturation of $5 \mathrm{~min}$ at $94^{\circ} \mathrm{C}, 30$ cycles each of $1 \mathrm{~min}$ denaturation at $94^{\circ} \mathrm{C}$, annealing of $1 \mathrm{~min}$ at $55^{\circ} \mathrm{C}$ and 2 min extension at $72^{\circ} \mathrm{C}$ was carried out followed by a final extension for $7 \mathrm{~min}$ at $72^{\circ} \mathrm{C}$. The PCR products were stored at $-20^{\circ} \mathrm{C}$ until further use. PCR product was visualized using agarose gel electrophoresis.

\section{Results}

The results of the evaluation of three viral concentration and extraction methods are presented in Figure-1. Concentration of virus using proteinase $\mathrm{K}$ and lysis buffer yielded better result than concentration by PEG 8000 in samples with lowest concentration of virus. Virus could be detected by RT-PCR in all the three dilutions $\left(10^{7}\right.$ to $10^{9}$ viral particles $\left./ \mathrm{ml}\right)$ in samples 


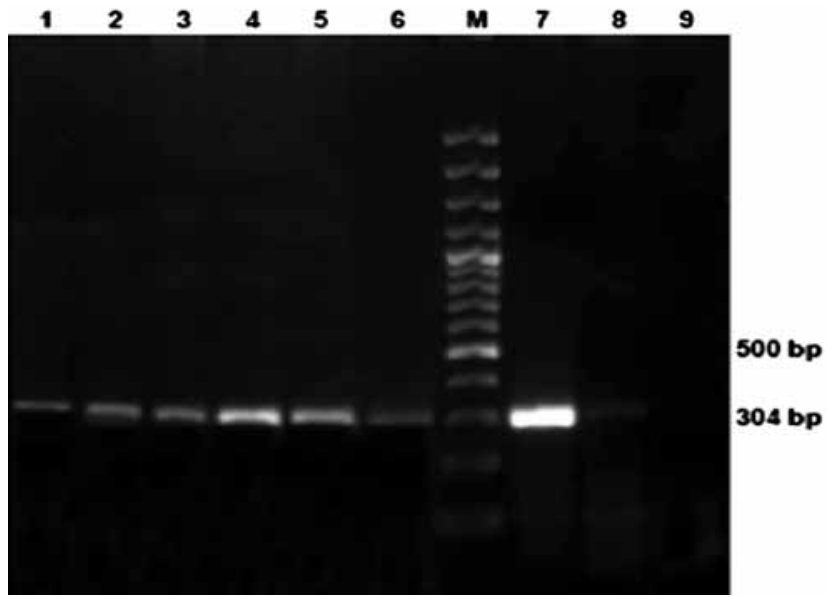

Figure-1: Concentration of rotavirus by various methods; Lane M: 100 bp plus ladder, Lane 1-3 proteinase $\mathrm{K}$ concentration method (10 to the power 9,10 to the power 8 and 10 to the power 7 viral paricles/ml), Lane 4-6 concenteration by lysis buffer ( 10 to the power 910 to the power 8 and 10 to the power 7 viral paricles/ml), Lane 7-9 concenteration by PEG 8000 (10 to the power 9,10 to the power 8 and 10 to the power 7 viral paricles $/ \mathrm{ml}$ )

concentrated by proteinase $\mathrm{K}$ and lysis buffer method. Among these two methods proteinase $\mathrm{K}$ treatment was better as it showed better amplification of the highest dilution $\left(10^{7}\right)$ used. However in PEG method, virus could be detected in only two dilutions.

\section{Discussion}

The development of nucleic acid amplification methods to detect viral contamination in shellfish is complicated by the following two factors: (i) they have low viral titers, and (ii) they contain compounds that interfere with enzymatic nucleic acid amplification reactions. Elimination of inhibitors is difficult to evaluate and depending on the time of the year and shellfish life, different compounds may be present [13]. To detect viruses using PCR, it is important that the samples of nucleic acids from the original specimens be as pure as possible. The purification stage is particularly important when the virus concerned is an RNA virus, for which a reverse transcription (RT) stage is necessary. Indeed, the high susceptibility of reverse transcriptase to interfering or inhibitory substances is a major limiting factor in amplification reactions $[14,15]$. The three concentration and extraction methods evaluated in the study were proteinase $\mathrm{K}$ method, lysis buffer method and poly-ethylene glycol precipitation. In our study extraction and concentration by proteinase $\mathrm{K}$ showed the best result followed by lysis buffer method and PEG. Similar results were obtained by Tibollo and coworkers [16]. In their study concentration by proteinase $\mathrm{K}$ was found to be faster and sensitive when compared to PEG. The European Committee for Standardization (CEN) has approved the proteinase K method as it is simpler and has shown adequate results. Proteinase $\mathrm{K}$ treatment have shown a more efficacious removal of PCR inhibiting substances in another study by Di Pasquale and coworkers [17].

\section{Conclusion}

Among the three methods compared, use of proteinase $\mathrm{K}$ was found to be the best method for concentration of rotavirus from shellfish samples. Concentration of virus by proteinase $\mathrm{K}$ could detect virus in all the three serial dilutions of virus and is also easier to perform when compared to precipitation with PEG 8000.

\section{Author's contributions}

This study was a part of VM's M.V.Sc. thesis under the guidance of KNB. KNB and SR designed the experiment, sample collection was done by $\mathrm{VM}$ and DAR. Experiment was performed by VM and assisted by SR, KML, HVM under guidance of KNB. Manuscript preparation was supervised, reviewed and edited by KNB and AK. All authors read and approved the final manuscript.

\section{Acknowledgements}

The authors are thankful to the Director, Indian Veterinary Research Institute, Izatnagar for providing necessary facilities to carry out this work. The research was funded by ICAR, India.

\section{Competing interests}

The authors declare that they have no competing interests.

\section{References}

1. Fusco, G., Aprea, G., Galiero, G., Guarino, A. and Viscardi, M. (2013) Escherichia coli, Salmonella spp., Hepatitis A Virus and Norovirus in bivalve molluscs in Southern Italy. Vet. Ital., 49 (1), 55-58.

2. Le Guyader, F., Haugarreau, L., Miossec, L., Dubois, E. and Pommepuy, M. (2000) Three-year study to assess human enteric viruses in shellfish. Appl Environ Microbiol, 66(8): 3241-3248.

3. Nakagawa-Okamoto, R., Arita-Nishida, T., Toda, S., Kato, H., Iwata, H., Akiyama, M., Nishio, O., Kimura, H., Noda, M., Takeda, N. and Oka, T. (2009) Detection of multiple sapovirus genotypes and genogroups in oyster-associated outbreaks. Jpn JInfect Dis., 62(1): 63-66.

4. Schwab, K.J., Neill, F.H., Estes, M.K., Metcalf, T.G. and Atmar, R.L. (1998) Distribution of Norwalk virus within shellfish following bioaccumulation and subsequent depuration by detection using RT-PCR. J Food Prot, 61: 1674-1680. 
5. Jiang, X., Wang, J., Graham, D.Y. and Estes, M.K. (1992) Detection of Norwalk virus in stool by polymerase chain reaction. J. Clin. Microbiol, 30: 2529-2534.

6. Shieh, Y.S.H., Wait, P., Tai, L. and Sobsey, M.D. (1995) Methods to remove inhibitors in sewage and other fecal wastes for enterovirus detection by the polymerase chain reaction. J. Virol. Methods, 54: 51-66.

7. Wilson, I. G. (1997) Inhibition and facilitation of nucleic acid amplification. Appl. Environ. Microbiol., 63:3741-3751.

8. Le Guyader, F.S., Parnaudeau, S., Schaeffer, J. and Atmar, L. R. (2009) Detection and Quantification of Noroviruses in Shellfish. Appl. Environ. Microbiol, 3: 618-624.

9. Jothikumar, N., Cromeans, T.L., Sobsey, M.D. and Robertson, B.H. (2005) Development and evaluation of a broadly reactive TaqMan assay for rapid detection of hepatitis A virus. Appl Environ Microbiol, 71:3359-3363.

10. Lowther, J.A., Avant, J.M., Gizynski, K., Rangdale, R.E. and Lees, D.N. (2010) Comparison between Quantitative RealTime Reverse Transcription PCR Results for Norovirus in Oysters and Self-Reported Gastroenteric Illness in Restaurant Customers. JFood Prot, 73:305-311.

11. Alouini, M.D. and Sobsey, S. (1995) Evaluation of an extraction-precipitation method for recovering hepatitis A virus and poliovirus from hardshell clams (Mercenaria mercenaria). Water Sci. Technol, 31:465-469.

12. Nenonen, N.P., Hannoun, C., Olsson, M.B. and Bergstrom, T. (2009) Molecular analysis of an oyster-related norovirus outbreak. J. Clin. Virol, 45:105-108.

13. Di Girolamo, R., Liston, J. and Matches, J.R. (1970) Survival of virus in chilled, frozen, and processed oysters. Appl Microbiol, 20: 58-63.

14. Hussain, M., Seth, P. and Broor, S. (1995) Detection of group A rotavirus by reverse transcriptase and polymerase chain reaction in faeces from children with acute gastroenteritis. Arch Virol, 140:1225-1233.

15. Wilde, J., Eiden, J. and Yolken, R. (1990) Removal of inhibitory substances from human fecal specimen for detection of group A rotaviruses by reverse transcriptase and polymerase chain reactions. J. Clin. Microbiol, 28: 13001307.

16. Tibollo, S., Zoni, R., Mariani, E., \& Sansebastiano, G.E. (2011) Study on the Application of a New Method for the Viral Detection of Caliciviruses in Foodstuffs. Rom. Biotechnol. Lett, 16(6): 87.

17. Di Pasquale, S., Paniconi, M., De Medici, D., Suffredini, E. and Croci, L. (2009) Duplex real time PCR for the detection of hepatitis A virus in shellfish using feline calicivirus as a process control. J. Virol, 163: 96-100.

$* * * * * * * *$ 